\title{
IMPROVING SCIENTIFIC ARTICLE WRITING SKILL THROUGH COLLABORATIVE WRITING LEARNING TECHNIQUE
}

\author{
Yulia Sri Hartati ${ }^{1}$, Yumna Rasyid ${ }^{2}$ \\ STKIP PGRI of West Sumatra ${ }^{1}$ \\ Universitas Negeri Jakarta ${ }^{2}$ \\ vuliasrihartati@yahoo.co.id ${ }^{1}$ \\ yumnarasyid@ unj.ac.id $^{2}$
}

\begin{abstract}
The purpose of this research is to improve scientific writing skills through collaborative learning writing techniques students of Language and Literature Education STKIP PGRI Indonesia West Sumatra. This research is an action using Elliot action model consists of seven stages, namely the identification of the first step, findings and analysis of the facts, general planning, action, action observation, evaluation of the implementation of the action, and reflection and improvement. This research was conducted in three cycles. Sources of data in this study are students Session B Language Study Program and Literature Indonesia PGRI STKIP West Sumatra, class of 2014. The data were processed qualitatively and quantitatively. The results of the study during three cycles showed an increase in the average value of scientific writing skills through collaborative learning writing techniques at the end of the test. The average value of the test in cycle 1 is 56.56. The average value of the test in cycle 2 was 69.64 . The average value of the test in cycle 3 is 81 The average value of the test show that collaborative learning writing techniques can improve students' academic writing skills.
\end{abstract}

Keyword: Improving, Scientific Article , Collaborative Writing Learning Technique

Every individual has four language skills, namely listening, speaking, reading and writing. Writing skill is one of the skill that has complexity in its application process. This due to many factors that affect the process of writing, the mastery of the topic, the ability to select words, the ability to convey ideas through words, and the mastery of mechanic. The factors will contribute to the quality and the difficulties of writing. Some of these things make the writing as a skill that is difficult to do.

Writing is an activity that is less preferred and mastered by students. Based on the field observations, it is found that the results of student assignment in written form (paper or article) were not satisfactory. This is certainly an important focus for lecturers that writing scientific articles is important to be mastered by students. Therefore, the guidance in writing should be carried out to make it is not regarded as a troublesome activity.

Based on the observation conducted on students and lecturers at Study of Indonesia Language Education and Literature of PGRI STKIP West Sumatra, it was found that the students' low skill in 
writing scientific article is caused by several factors. First, the use of approaches, methods, and techniques at the teaching and learning was not maximal. Second, there was not feedback of the students' assignment because they were submitted at the end of the semester.

There some aspects used as the criteria in assessing scientific writing, namely: content, organization, vocabulary, language usage, and mechanics. The students' writing have not included the five elements properly. Therefore, there scientific writing are not the ones expected by the lecturers. The unsatisfactory results has been an initial data to do some improve toward the scientific writing skill many shortcoming were found in the scientific writing in the pre-test.

Based on the empirical data, the errors in the above scientific articles were also found in the majority of students' scientific articles. Therefore, the score or remarks of the scientific article writing is not expected. For the long-term interests, the unsupported experience of writing a scientific article will affect the real production of scientific articles. It means that when students summarize their thesis to be a published scientific article. It will need long process due to the errors.

In relation to the effort to improve the students' scientific article ability in writing is the lecturer can improve the quality of learning. One of the techniques that can be used is collaborative writing techniques.

Therefore, this study was conducted to look at the process and the results of scientific article writing skill improvement through collaborative writing learning techniques students of Indonesia Language and Literature Education STKIP PGRI West Sumatra.

Sokolik (2003:88) explains that writing is an activity that includes physical and mental activities, involving physical and mental processes. At the most basic level, writing is an activity physical to produce words or ideas in some media. On the other hand, writing is a mental activity to find ideas, to think how to express these ideas, and arrange them into statements and paragraphs for the readers.

Furthermore, Hyland (2003: 9) states" writing is a way of sharing personal meanings and writing courses emphasize the power of the individual to construct his or her own views on a topic. Writing is a way for someone to share something and writing require the attention of an individual to establish posts or her point of view on a topic. Therefore, writing is a way for someone to share his opinions.

Based on multiple experts opinion on the above, it can be concluded that the writing skills is an activity that involves physical and mental processes to convey thoughts, ideas, and desires to others by taking into account the elements of language using the language as the medium.

According Ba'in (2011: 111) scientific articles writing that are designed to appear in the journal or articles collection, written by following the fixed scientific guidance or scholarly mechanic. According to Djuroto and Bambang (2003:3), the article is writing that contains the authors' opinion and can be original ideas from other sources, references, libraries, and the statements. Based on the above opinion, it can be concluded that the skills of writing scientific articles is students' skill to make paper containing the author's ideas and opinion, original ideas or from other sources, analysed and written, following procedures scientific procedures and the guidance that have been agreed.

According to Hartley (2008: 201), there are some aspects that must be considered in writing a scientific article, namely, title, author name, abstract and keywords, introduction, methods, discussion, conclusion, and bibliography. There are several elements that must be fulfilled by a scientific article. According to Ibn (:29-33), the structure of research based scientific articles is title, author name, abstract 
and keywords, introduction, methods, discussion, conclusions and recommendations, and a list of references.

Louth, McAllisteer and McAllister (1993: 215-224) claims that collaborative writing technique is the interaction of several people in a group in the process of making an article and the group is responsible for the final outcome of these activities.

Collaborative learning writing technique according to Bosley (1990: 27-33) is the effort of two or more people working together to produce an article in which all group members who are directly involved should have the responsibility for the result that they seek. In these case, Bosely stated that in the collaborative writing process, regardless of the results obtained, it is the fix group's result.

Based on the experts' opinion, it can be concluded that collaborative techniques writing is a learning process that is carried out by a pupil/ student to produce an article. In the process, they share ideas, roles, and responsibility for the final product.

\section{METHOD}

The method used was Elliot's research models which has seven stages, namely, the identification of the first step, reconnaissance (findings and analysis of the facts), general planning, action, observation of actions, evaluation of the implication of the action, and reflection and improvement. This research was conducted in three cycles. The subjects were students of session B Study Program Language and Literature of West Sumatra Indonesia PGRI STKIP academic year 2015/2016.

Data collection techniques used in this research is interview, observation, field notes, test, and questionnaire(Creswell, 2012: 212). The implementation of the action requires collaborators as peer who helped research. Therefore, the data collected through observation with an observation and field notes. Students' result data were collected by giving assessment related to the skills of writing scientific articles by examining aspects of the writing, contents of article, organization of the article, vocabulary, language usage, and mechanics. Interview and questionnaire data collected in the form of sheet interview and questionnaire.

Data analysis in this study was divided into qualitative and quantitative data. The qualitative data in this study is the observation of students' activities and lecturer's during the learning process. Quantitative data were done using descriptive statistics. Data were analysed using descriptive statistics, presenting in the form of tables and diagram. All of the data will be interpreted based on the research findings. The quantitative data that will be analysed, derived from article writing test carried out by the students.

\section{RESULT AND DISCUSSION}

\section{Writing Skill Improvement Process through The Scientific Article Writing Collaborative Learning Technique}

In cycle 1 students were divided into several groups to train in scientific articles collaboratively. The first step in which students share the duties and responsibilities to complete parts of a scientific article that will be done. At this stage, students share ideas and write down things that will described in a scientific article based on the exercises given. The question is made based on the results of existing studies. The question problem contains the outline of the research that will be developed by the student 
to become a scientific article. The process of sharing this idea help students in writing. This is consistent with the objectives of the collaborative learning techniques proposed by Alwasilah (2007: 50) that by collaborating can help students correct mistakes through correction and comment on the editing stage.

Based on the learning condition in cycle 1, in the cycle 2, the learning steps of collaborative learning techniques are modified varied. If in cycle 1, the sharing of ideas is done only in the group that has been set. In the cycle 2, the process is performed in two stages. The first phase, involving other groups and in the second stage, in the baseline group.

The learning step is done in accordance with the collaborative learning strategies proposed by $\mathbf{J}$ Onrubia\& Engel, A (2009: 1256-1265) in the form of integrating sequential construction. That is, a member of the group presents an initial document, members of the group successively contribute to the early writings. Things to do are proposing improvements or modifications, which were be decided the article is accepted or not by the group.

The learning process by applying scientific article writing collaborative learning techniques with a varied pattern impact the students' learning process. After a scientific article is completed collaboratively by each group, the next activity is revising process. This activity is done in a different way with the previous cycle.

In cycle 3, learning by using a collaborative writing technique gives more emphasis on the use of language mastery and mechanical components. Therefore, the lecturer and collaborator plan learning collaborative writing in pairs and groups. Things to do during the learning process is reading writing connection in pairs, students correct the scientific articles each other. New scientific articles, rewritten based corrections have been made. In addition, learning continues in the form of the group. In this group, collaborative process was repeated to improve scientific articles.

\section{Result of Scientific Articles Writing Skills Improvement through Technical Education Collaborative Writing}

Application of collaborative learning writing techniques in teaching writing scientific article can involve students in the process of collaboration. This involvement can be seen from the improvement of every activity performed by students.

After given the treatment in the process cycle action 1 scientific article writing skill through writing collaborative learning techniques, students who completed the writing scientific articles in cycle 1 reached to 4 people. There were 21 students who were yet complete. Students who did not complete were categorized into satisfactory (7), unsatisfactory (10), and not very satisfactory (4). In cycle 1, based on the results of the action against 25 students, it can be seen in the increase of the score of the scientific article writing. In the preliminary test, the average score of students only reached 43.36 , whereas at the end of the test cycle 1 score average 56.16 in cycle 1 . Based on a scientific article writing completeness criteria was 70 there are many students who are not yet complete. The average of nearly all components of a scientific article still does not meet the standards expected.

Based on the test carried out in cycle 2, the following data are obtained , students who scored 6680 of 26 people, students who earn grades 56-65 amounted to 8 people, students who earn grades 46-55 amounted to one person, and no students who scored 00-45. Highest score on the test cycle 2 was 80 and the lowest score was 52. In cycle 2 score averaged 69.6 . 
In order to change the learning outcomes in cycle 3, the learning of grammar and mechanics is planned. This is to reduce the doubts of students in editing their article. The test results of cycle 3 , students who completed are in honor (11) and satisfactory (14).

In cycle 3 , based on the results of the action against 25 students can be seen in the increase in the value of writing a scientific article. In cycle 2, the average score of students reached only 69.6, while the final test cycle of three score average of more than 81 in cycle 3 . Assessment of students categorized as very satisfactory $44 \%$ (11 people) an a satisfactory $56 \%$ (14 people).

\section{CONCLUSION}

The application of collaborative learning writing techniques in writing a real scientific article can involve students in the process of collaboration. This involvement can be seen from the increasing every activity performed by students. Students who previously passive in learning become more active. It can be seen from the desire of students to participate in all activities of collaboration. The process of learning by using writing collaborative learning techniques provide opportunities for students to practice writing with enough time. The problem that arise in writing scientific articles are expresses ideas, using linguistic elements, and mechanics.

\section{REFERENCE}

Alwasilah, Chaedar dan Senny Suzanna, Pokoknya Menulis: Cara Menulis dengan Metode Kolaborasi.Bandung: PT. Kiblat Buku Utama, 2007.

Ba'in, Bimbingan Penulisan Ilmiah. Yogyakarta:Ombak,2012

Bosley, D. S. "An Essensial Bibliografy on Collaborative Writing. Buletin of the Association for Business Communication.” Vol. 54(2), 1990

Creswell, John W. Educational Research: Planning, Conducting, and Evaluating Quantitative and Qualitative Research, 2012.

Djuroto dan Bambang. Menulis Artikel \& Karya Ilmiah. Bandung: Remaja Rosdakarya, 2003.

Hylan, Ken. Second Language Writing. New York: Cambridge University Press, 2003.

Ibnu, Suhadi. Dkk. Menulis Artikel untuk Jurnal Ilmiah. Universitas Negeri Malang: UM Press, 2000

McAllister, C., R Louth, \& McAllister, H. A. "The effects of collaborative writing techniques on freshman writing and attitudes". (The Journal of experimental education, vol. 61(3), 1993.

Onrubia, J \& Engel, A. "Strategies for collaborative writing and phases of knowledge construction in CSCL environments". (Journal Computers \& Education, 53(4), 2009.

Sokolik, Maggie. 'Writing', dalam David Nunan (ed). Practical English Language Teaching. Boston: McGraw Hill, 2003. 
International Journal of Language Education and Culture Review, Vol. 3 (1), June 2017

Sugono, Dendy. Mahir Berbahasa Indonesia dengan Benar. Jakarta: Gramedia, 2009. 